\title{
Review: The Role of Cannabinoids on Esophageal Function-What We Know Thus Far
}

\author{
Jonathan Gotfried, ${ }^{1,2}$ Rahul Kataria, ${ }^{1,2}$ and Ron Schey ${ }^{1,2, *}$
}

\begin{abstract}
The endocannabinoid system (ECS) primarily consists of cannabinoid receptors (CBRs), endogenous ligands, and enzymes for endocannabinoid biosynthesis and inactivation. Although the presence of $C B R s$, both $\mathrm{CB}_{1}$ and $\mathrm{CB}_{2}$, as well as a third receptor (G-protein receptor 55 [GPR55]), has been established in the gastrointestinal (Gl) tract, few studies have focused on the role of cannabinoids on esophageal function. To date, studies have shown their effect on GI motility, inflammation and immunity, intestinal and gastric acid secretion, nociception and emesis pathways, and appetite control. Given the varying and sometimes limited efficacy of current medical therapies for diseases of the esophagus, further understanding and investigation into the interplay of the ECS on esophageal health and disease may present new therapeutic modalities that may help advance current treatment options. In this brief review, the current understanding of the ECS role in various esophageal functions and disorders is presented.
\end{abstract}

Keywords: cannabinoid receptors; endocannabinoid; esophagus; medicinal marijuana; motility

\section{Overview of Endocannabinoid System}

The endocannabinoid system (ECS) primarily consists of cannabinoid receptors (CBRs), endogenous ligands, and enzymes for endocannabinoid biosynthesis and inactivation. ${ }^{1}$ The ECS plays an important role in regulation of synaptic transmission in the central and enteric nervous systems (ENS) through both excitatory and inhibitory effects, mediating a variety of physiological processes including pain sensation and modulation, motor function, inflammation, and immunity. ${ }^{2}$

CBRs belong to the superfamily of G-protein-coupled receptors and are expressed in two main forms, $\mathrm{CB}_{1}$ and $\mathrm{CB}_{2}{ }^{3} \mathrm{CB}_{1}$ is mainly expressed in central and peripheral neurons, including the ENS, whereas $\mathrm{CB}_{2}$ is mostly expressed by inflammatory/immune cells. ${ }^{4-6}$ The ubiquitous distribution of CBRs in the ENS and gastrointestinal (GI) tract highlights its role in GI health and disease including motility, inflammation and immunity, intestinal and gastric acid secretion, nociception and emesis pathways, and appetite control $^{7-9}$ (Table 1).
The $\mathrm{CB}_{1}$ receptor plays a role in intestinal motility by attenuating both large and small bowel muscle tone when activated. ${ }^{10-13}$ Within the upper GI tract, activation of $\mathrm{CB}_{1}$ decreases intragastric pressure and delays gastric emptying through inhibition of excitatory neurons. ${ }^{14,15}$ As demonstrated in rodent models, $\mathrm{CB}_{1}$ receptors play a role in energy regulation by driving consumption of food high in dietary fat. ${ }^{16}$ After sham feeding in rats with high-fat foods, upregulation of $\mathrm{CB}_{1}$ receptors was found in rat small intestine, leading to inhibition of neural signaling events of satiety to suppress feeding. These findings suggest that $\mathrm{CB}_{1}$ acts through a positive feedback loop after dietary fat exposure to stimulate further consumption of higher energy foods. In another study, pharmacological inhibition of $\mathrm{CB}_{1}$ led to decreased amount of refeeding in rats after food deprivation, highlighting $\mathrm{CB}_{1}$ receptor's role in appetite regulation. ${ }^{17}$ In addition, $\mathrm{CB}_{1}$ was found to be upregulated in rats fed a high fat, high caloric Western diet (WD). It was also suggested to play a role in hyperphagia

${ }^{1}$ Department of Gastroenterology, Temple University Hospital, Philadelphia, Pennsylvania.

${ }^{2}$ Lewis Katz School of Medicine, Temple University, Philadelphia, Pennsylvania. 
Table 1. Known Functions of the Endocannabinoid System Along the Upper Alimentary Tract

\begin{tabular}{|c|c|c|}
\hline Function & Brief summary & Related studies \\
\hline Appetite regulation & $\begin{array}{l}\text { 1. Stimulates appetite, especially high energy, fatty foods } \\
\text { 2. Induces hyperphagia, potential target for obesity therapy, generates } \\
\text { hunger signal }\end{array}$ & $\begin{array}{l}\text { Argueta and DiPatrizio } \\
\text { DiPatrizio et al. }{ }^{17} \\
\text { DiPatrizio et al. }{ }^{16}\end{array}$ \\
\hline Nociception/emesis & $\begin{array}{l}\text { 1. Stimulation of } \mathrm{CB}_{1} \text { receptor in CNS leads to nausea, therapeutic } \\
\text { target for antiemetic effect of exogenous cannabinoid therapy }\end{array}$ & $\begin{array}{l}\text { Van Sickle et al. }{ }^{19} \\
\text { Rock and Parker }\end{array}$ \\
\hline Motility & $\begin{array}{l}\text { 1. Multiple receptors }\left(\mathrm{CB}_{1} \text { and } \mathrm{CB}_{2}\right) \text { thought to influence contractile } \\
\text { and relaxant forces in stomach } \\
\text { 2. Modulates intestinal propulsion, GPR55 inhibits whole gut transit } \\
\text { time, modulation of cholinergical and vagal stimulation } \\
\text { of upper } \mathrm{Gl} \text { tract } \\
\text { 3. Enhances gut motility in setting of inflammation }\end{array}$ & $\begin{array}{l}\text { Hornby and Prouty } \\
\text { Yuece et al. }{ }^{12} \\
\text { Storr et al. }{ }^{12} \\
\text { Izzo et al. }^{24} \\
\text { Yang et al. } \\
\text { Li et al. }{ }^{26}\end{array}$ \\
\hline Gastric acid and intestinal secretions & $\begin{array}{l}\text { 1. Exhibits antisecretory effects on gastric acid } \\
\text { 2. Implicated in mitigating inflammation and mucosal damage in GERD } \\
\text { 3. Effect on transient lower esophageal relaxation }\end{array}$ & $\begin{array}{l}\text { Adami et al. }{ }^{15} \\
\text { Calabrese et al. } \\
\text { Lehmann et al. }\end{array}$ \\
\hline Inflammation and immunity & $\begin{array}{l}\text { 1. Anti-inflammatory effects in esophageal reflux disease } \\
\text { 2. } \mathrm{CB}_{2} \text { receptor downregulates inflammation and associated hypermotility in } \\
\text { disease state }\end{array}$ & $\begin{array}{l}\text { Calabrese et al. } \\
\text { Izzo }^{23}\end{array}$ \\
\hline Analgesia & 1. Increases pain threshold & $\begin{array}{l}\text { Clapper et al. } \\
\text { Malik et al. }\end{array}$ \\
\hline
\end{tabular}

CNS, central nervous system; GERD, gastroesophageal reflux disease; Gl, gastrointestinal; GPR55, G-protein receptor 55.

after antagonism of $\mathrm{CB}_{1}$ with an inhibitor led to decreased food intake in rats fed a WD for 60 days. ${ }^{18}$

$\mathrm{CB}_{2}$ receptors located in the central nervous system (CNS) have been shown to play a role in the emetic pathway; however, the receptor has also been found in inflammatory tissue and immune cells (plasma cells and macrophages) throughout the GI tract. ${ }^{19-22} \mathrm{CB}_{2}$ is expressed in the GI tract but less extensively than $\mathrm{CB}_{1}$ receptors. ${ }^{23}$ Evidence that upregulation of $\mathrm{CB}_{2}$ receptors occurs in patients with inflammatory bowel disease suggests that these receptors play a critical role in colonic inflammation. ${ }^{7}$ Distinct from $\mathrm{CB}_{1}$ receptors effect on motility, $\mathrm{CB}_{2}$ receptors may further regulate motility in pathophysiological states with its expression being upregulated in inflammatory disease states. ${ }^{5,24}$

Presence of CBRs in human esophageal epithelium was first demonstrated in a study comparing patients with nonerosive esophageal reflux disease (NERD) and erosive esophageal reflux disease (ERD) to normal controls. ${ }^{25}$ The authors found increased expression of $\mathrm{CB}_{1}$ mRNA in NERD patients compared with erosive esophagitis, but overall less expression compared with normal controls. Interestingly, $\mathrm{CB}_{1}$ protein expression was similar to patients with ERD, whereas NERD patients showed increased $\mathrm{CB}_{1}$ receptor levels when compared with healthy controls (Fig. 1). Although other GI inflammatory conditions have increased $\mathrm{CB}_{1}$ activity, there may be contribution of the inflammatory microenvironment that alters $\mathrm{CB}_{1}$ gene expression. ${ }^{24}$
Recently, a potential third CBR has been identified with implications in the GI tract. G-protein receptor 55 (GPR55) shares 13-15\% sequence homology with the $\mathrm{CB}_{1}$ and $\mathrm{CB}_{2}$ receptors and responds to a multitude of endogenous and exogenous cannabinoid ligands as well as several lipids. ${ }^{26}$ A recent study found activation of GPR55 after administration of a synthetic agonist slowed down whole-gut transit in mice in vivo, suggesting GPR55 may be involved in the regulation of gut motility. ${ }^{27}$

Endocannabinoids are endogenously produced ligands that exert effects on CBRs. The major ligands, anandamide (AEA) and 2-arachidonylglycerol (2-AG), play a role in maintaining GI homeostasis and have been found at increased levels in GI disease states, including celiac disease, diverticulosis, and colorectal cancer. $^{28-30}$ Exogenous cannabinoids, both plant-derived phytocannabinoids (cannabis sativa) and synthetic cannabinoids, also directly activate CBRs. They have been shown to play a role in both GI pathophysiology (e.g., cannabinoid hyperemesis syndrome) and therapies (e.g., antiemetics and appetite stimulant) ${ }^{31}$

Although both $\mathrm{CB}_{1}$ and $\mathrm{CB}_{2}$ receptors have been found in the esophagus, few studies have focused on the role of cannabinoids on esophageal function. ${ }^{21}$ Thus far, the role of GPR55 in esophageal motility has not been established. Given the varying and sometimes limited efficacy of current medical therapies for diseases of the esophagus, further understanding and 

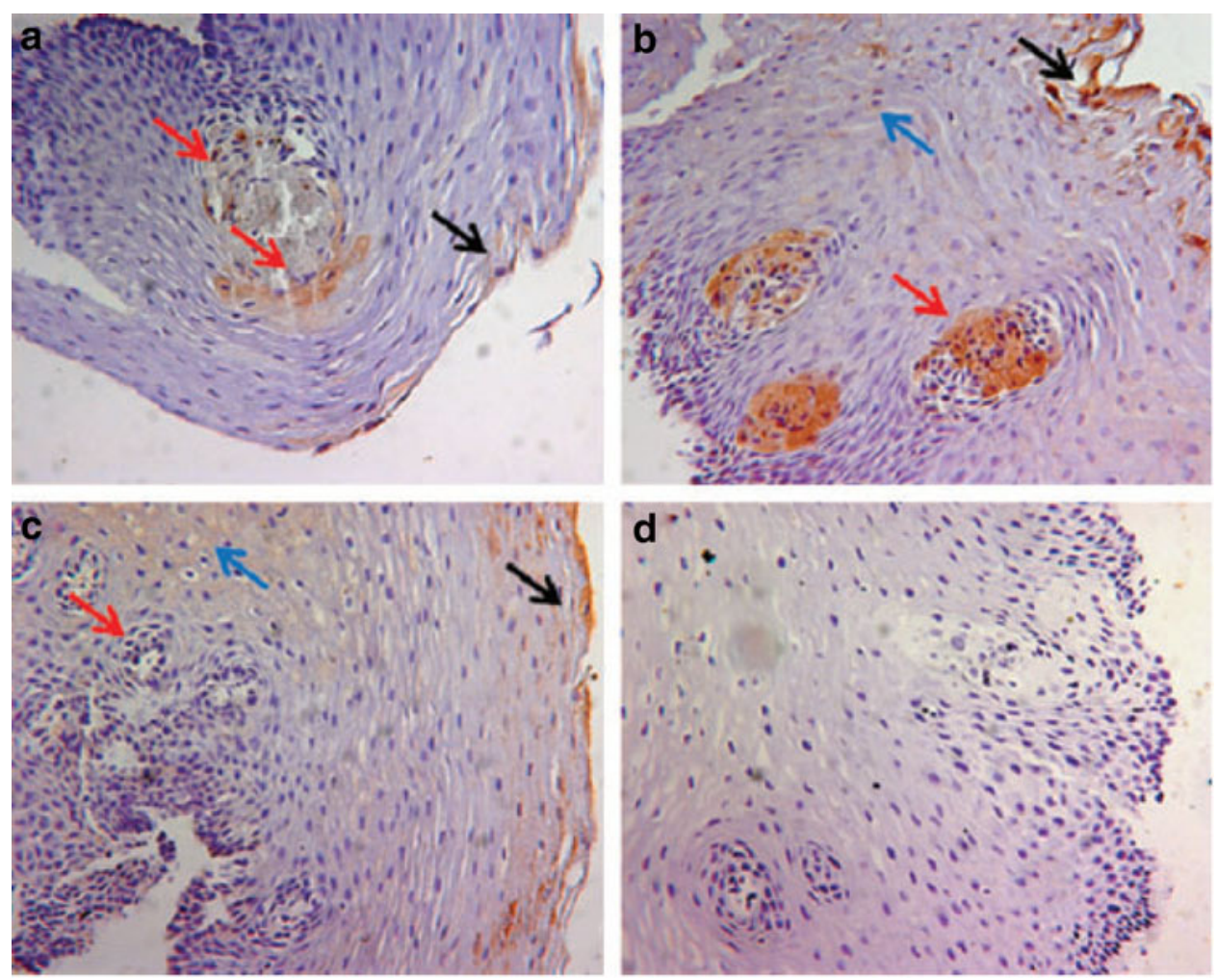

FIG. 1. Immunostaining of $\mathrm{CB}_{1}$ receptor in histological sections of esophageal mucosa. Healthy subjects (a) show a weak positive staining localized in mature squamous cells (black arrow) and in connectival papillae (red arrows). NERD patients (b) show $\mathrm{CB}_{1}$ receptor expression in mature squamous cells (black arrow), in squamous cells (blue arrow), and in connectival papillae (red arrow). ERD patients (c) show $\mathrm{CB}_{1}$ positivity only in mature squamous cells (black arrow) and in squamous cells (blue arrows), whereas connectival papillae appear negative (red arrow). $\mathrm{CB}_{1}$ staining disappeared in esophageal mucosa (d) when $\mathrm{CB}_{1}$ blocking peptide was incubated with $\mathrm{CB}_{1}$ antibody. ERD, erosive esophageal reflux disease; NERD, nonerosive esophageal reflux disease. Reprinted with permission from Calabrese et al. ${ }^{25}$

investigation into the interplay of the ECS on esophageal health and disease may present new therapeutic modalities that may help advance current treatment options. In this review, the current understanding of the role of ECS in various esophageal functions and disorders is presented.

\section{Swallowing Mechanism}

The swallowing reflex is an important mechanism in controlling acid exposure in the esophagus, whereby increased swallowing decreases stasis and reduces acidic and nonacidic reflux. The role of the swallowing reflex in reducing reflux has been demonstrated after observation that supine sleeping patients experienced a decreased spontaneous swallowing reflex during 24-h $\mathrm{pH}$ monitoring, leading to increased acid and nonacid exposure. ${ }^{32} \mathrm{CB}_{1}$ receptor activation has been shown to decrease spontaneous swallows in human and animal studies. One study on dogs found administration of $\mathrm{CB}_{1}$ agonist suppressed spontaneous swallowing in a dosedependent manner with an $>80 \%$ decrease in spontaneous swallows at high doses $(57 \mathrm{nmol} / \mathrm{kg}) .{ }^{33}$ The authors noted that although administration of $\mathrm{CB}_{1}$ agonist decreased transient lower esophageal sphincter relaxations (TLESRs) thereby decreasing reflux events, the concomitant decrease in spontaneous swallows and clearance of refluxate potentially limit the benefits of decreasing TLESRs. The mechanism of action of CBRs on swallowing mechanism is likely centrally located through endogenous cannabinoid action, modifying synaptic neurotransmitter release. ${ }^{34}$ The swallowing reflex, evoked by repetitive electrical stimulation of the superior 
laryngeal nerve in rats, was analyzed with and without combinations of both $\mathrm{CB}_{1}$ and $\mathrm{CB}_{2}$ agonists and antagonists. $\mathrm{CB}_{1}$ receptor antagonist injected directly into the nuclear tractus solitarius blocked the action of intravenous-administered $\mathrm{CB}_{1}$ agonist. The only study in humans to date found administration of the combination $\mathrm{CB}_{1} / \mathrm{CB}_{2}$ agonist $\triangle 9$-THC resulted in a significant reduction in the number of swallows wherein high doses $(20 \mathrm{mg})$ led to a reduction in spontaneous swallows by $50 \%{ }^{35}$

\section{Esophageal Motility}

CBRs, specifically $\mathrm{CB}_{1}$, play a role in GI motility and have mainly been studied in the small intestine and colon. ${ }^{8,10}$ Only two studies have evaluated the effect of ECS on esophageal motility in humans. ${ }^{35,36}$ Administration of $\Delta 9$-THC decreased basal lower esophageal sphincter (LES) pressure in a nondose-dependent manner, with onset occurring $45 \mathrm{~min}$ after meal ingestion, maximal effect around $100 \mathrm{~min}$, followed by slow recovery. ${ }^{35}$ This was confirmed in another human study that administration of rimonabant, $\mathrm{a} \mathrm{CB}_{1}$ receptor antagonist, increased postprandial LES pressures in the first and second postprandial hours. ${ }^{36}$

Previous studies in animal models did not demonstrate CBR action influenced esophageal motility. Lehman et al. demonstrated that CBR agonism did not influence the extent of LES relaxation. Similarly, CBR antagonists had no influence on esophageal peristalsis. ${ }^{33} \mathrm{~A}$ recent case report suggested that exogenous phytocannabinoid use improved symptoms of dysphagia in a patient with manometric findings, consistent with type 3 achalasia. ${ }^{37}$ Others have suggested that exogenous cannabinoid use, like chronic opiate use, may produce motor findings similar to type 3 achalasia. ${ }^{38}$ The conflicting data support the need for further study of endo- and exogenous cannabinoids on esophageal motility. ${ }^{39}$

\section{Gastroesophageal Reflux Disease and TLESRs}

TLESRs are the predominant mechanism seen in gastroesophageal reflux disease (GERD). TLESRs occur after gastric stimuli, mainly distension, to relieve counteracting gastric pressure on the LES. ${ }^{40,41}$ The LES response to gastric distension is vagally mediated through communication of the LES and crural diaphragm with afferent gastric pathways, brainstem integrative centers (nucleas tractus solitarus and dorsal motor nucleus), and efferent inhibitory pathways. ${ }^{41}$ The action of CBRs on TLESRs and GERD was first demonstrated in animal models after the observation that administration of $\mathrm{CCB}_{1}$ agonist (WIN55,212-2) reduced the rate of TLESRs without altering the TLESRs latency or esophageal peristalsis. ${ }^{33}$ The authors concluded that the action of the CBRs on TLESRs most likely occured via central pathways because no effect on the extent of LES relaxation was seen. ${ }^{33,42,43}$ Absence of $\mathrm{CB}_{1}$ receptors in preganglionic vagal motor neurons projecting to the gastric fundus or LES further supports the assumption that $\mathrm{CB}_{1}$ does not directly participate in vagal motor output modulation and rather relies on central activation. ${ }^{42}$

Interestingly, the use of a $\mathrm{CB}_{1}$ receptor antagonist (rimonabant) in healthy human subjects enhanced postprandial LES pressure but unexpectedly decreased TLESRs. ${ }^{36}$ This contradicts earlier data in an animal model with dogs that showed rimonabant enhanced the rate of TLESRs and reflux events that received acidified meal and intragastric air insufflation. ${ }^{36}$ The authors attributed this discrepancy to different dosage, bioavailability, or interspecies differences of rimonabant. A possible explanation for the similar results from administrating CBR antagonist and agonists may be a result of rimonabant exerting potent $\mathrm{CB}_{1}$ receptor-independent pharmacological effects. ${ }^{44}$

Gastric accommodation may affect TLESRs and play an important role in development of GERD. ${ }^{45}$ Previous studies evaluated the effect of $\mathrm{CB}_{1}$ receptors on pain sensation during intragastric balloon distension, however, they did not find modulation of $\mathrm{CB}_{1}$ receptors with rimonabant-influenced mechanosensitivity of the proximal stomach. ${ }^{46}$ It should be noted that baclofen has been shown to decrease TLESRs rate and increase basal LES pressure while not affecting meal-induced fundic accommodation, suggesting that the mechanism may not be as simple as binary, an observation previously suggested by Lehmann et al. ${ }^{33}$ Other studies have suggested that using $\triangle 9$-THC inhibits gastric insufflation-induced LES relaxations in the decerebrate ferret, highlighting the need for further clarification of the relationship between gastric stimulation and TLESRs. ${ }^{10}$

The effect of CBRs on gastric emptying has been studied in humans although the data are limited and conflicting. ${ }^{48-51}$ Although there may be some influence of CBRs, gastric emptying itself does not necessarily correlate with fundus accommodation and activation of TLESRs.

The presence of CBRs in the esophagus, specifically those affecting TLESRs, offers a potential therapeutic target for treating GERD. Using $\triangle 9$-THC, Beaumont et al. demonstrated decreased rate of TLESRs in healthy volunteers who received 10 and $20 \mathrm{mg}$ of $\triangle 9$-THC on 
three occasions a week apart. ${ }^{35}$ Delta(9)-THC significantly reduced the number of TLESRs and caused a nonsignificant reduction of acid reflux episodes in the first postprandial hour. In addition, lower esophageal sphincter pressure and swallowing were significantly reduced by $\Delta(9)-$ THC $^{35}$ However, in the high dose of $\Delta 9$-THC ( $20 \mathrm{mg}$ ) group, central activity led to increased nausea and vomiting. Centrally acting $\mathrm{CB}_{1}$ receptor agonists produce the psychotropic effects and, therefore, selective targeting of peripheral $\mathrm{CB}_{1}$ receptors is necessary for effective therapy, with recent efforts to develop higher potency and effective $\mathrm{CB}_{1}$ agonists. ${ }^{52,53}$ Previous studies have looked at using $\mathrm{CB}_{1}$ antagonists; however, their therapeutic use is also limited by its side effect of major depression. ${ }^{54}$

Newer methodologies for understanding the pharmacodynamics and pharmacokinetics of medication effects on TLESRs have been developed that may provide more accurate modeling of drug concentrations and their effects. ${ }^{55}$

\section{Bronchoconstriction}

In patients with a chronic cough where lung disease, environmental exposure, and medications have been excluded, GERD is often a major cause. ${ }^{56}$ The two main mechanisms implicated in reflux-related cough are microaspiration of refluxate and stimulation of vagal innervation of the esophagus, leading to esophagobronchial reflex arc. The $\mathrm{CB}_{2}$ receptor has been shown to play a role in inhibiting bronchoconstriction and microvascular leakage in reflux models using guinea pigs. After infusion of intraesophageal $\mathrm{HCl}$, the inhibitory effect of bronchoconstriction by a $\mathrm{CB}_{1}$ agonist (WIN55,212-2) was blocked after administration of a $\mathrm{CB}_{2}$ antagonist (SR 144528) but not after $\mathrm{CB}_{1}$ receptor antagonist, demonstrating $\mathrm{CB}_{2}$ receptor's role as a downregulatory mechanism of sensory nerve activation. ${ }^{57} \mathrm{CB}_{2}$ receptor activation in models of direct airway damage has been shown to play an active role in reducing inflammation, potentially supporting protective role of $\mathrm{CB}_{2}$ in microaspiration of refluxate. ${ }^{58}$

\section{Visceral Hypersensitivity and Pain}

Functional esophageal disorders are defined as the presence of esophageal symptoms in the absence of structural, inflammatory, or motor abnormalities. ${ }^{59}$ Proposed pathophysiological mechanisms include alterations in neural processing between peripheral triggers and central perception of esophageal symptoms. ${ }^{60}$ CBRs likely play a role in pain sensation and modulation through visceral antinociceptive action. ${ }^{61}$ Previous studies have demonstrated an analgesic effect of cannabinoids in animal models through both $\mathrm{CB}_{1}$ and $\mathrm{CB}_{2}$ activation. ${ }^{62-64}$ In one important study, upregulation of the endocannabinoid AEA through inhibition of its degrading enzyme led to an attenuated behavioral response to noxious stimuli in rodents. ${ }^{65}$ This suggests a central role of $\mathrm{CB}_{1}$ receptors in mitigating pain-related inputs to the CNS.

There are few studies of visceral sensitivity in the esophagus and the effects of CBR modulation. In a randomized, placebo controlled trial, administration of dronabinol for 1 month increased the threshold for first sensation, pain frequency, and intensity of pain during an esophageal balloon distention test. ${ }^{66}$ Notably, anxiety and depression indices were unchanged after dronabinol administration. The mainstay of functional esophageal disorders relies on tricyclic antidepressants, selective serotonin reuptake inhibitors, and serotonin norepinephrine reuptake inhibitors, all of which have been found to influence psychiatric parameters, highlighting a possible difference in mechanism of action. ${ }^{60}$

\section{Role in Esophageal Neoplasm}

Cannabinoids inhibit tumor cell growth and induce apoptosis by modulating cell signaling pathways. ${ }^{67}$ Decreased frequency of CNR-1 gene, the gene encoding $\mathrm{CB}_{1}$ receptor, expression was found in tissue of esophageal cancer patients (10.8\%) compared with controls (60.0\%), and its presence is considered an independent predictor of survival. ${ }^{68}$ However, recently a multivariate analysis revealed that $\mathrm{CB}_{1}$ receptor overexpression was independently associated with poor prognosis $(p=0.019)$. Biological analysis of $\mathrm{CB}_{1}$ receptor overexpression using esophageal squamous carcinoma cell lines revealed that $\mathrm{CB}_{1}$ receptor activation appeared to promote cell proliferation and invasion. ${ }^{69}$ Thus, the role of $\mathrm{CB}_{1}$ receptor expression in tumorogenesis needs to be further evaluated.

\section{Conclusion}

A more thorough understanding of the ECS in esophageal function and disease is needed. Recently, there has been a push to legalize cannabis for both medicinal and recreational use. There have also been reports of increasing use of both plant-derived cannabis and synthetic cannabinoids in the United States. ${ }^{70}$ This may allow additional studies to be added to the few human studies to date on the effect of cannabinoid use in humans. Further study in this area is imperative for the development of future therapeutic potential of utilizing the ECS. 


\section{Authors' Contributions}

J.G. was involved in literature review and is the primary author. R.K. was involved in literature review. R.S. was involved in study conceptualization and reviewed the article.

\section{Author Disclosure Statement \\ No competing financial interests exist.}

\section{References}

1. De Petrocellis L, Di Marzo V. An introduction to the endocannabinoid system: from the early to the latest concepts. Best Pract Res Clin Endocrinol Metab. 2009;23:1-15.

2. Aizpurua-Olaizola O, Elezgarai I, Rico-Barrio I, et al. Targeting the endocannabinoid system: future therapeutic strategies. Drug Discov Today. 2017;22:105-110.

3. Coutts AA, Irving AJ, Mackie K, et al. Localisation of cannabinoid CB(1) receptor immunoreactivity in the guinea pig and rat myenteric plexus J Comp Neurol. 2002;448:410-422.

4. Matsuda LA, Bonner TI, Lolait SJ. Localization of cannabinoid receptor mRNA in rat brain. J Comp Neurol. 1993;327:535-550.

5. Duncan M, Mouihate A, Mackie K, et al. Cannabinoid CB2 receptors in the enteric nervous system modulate gastrointestinal contractility in lipopolysaccharide-treated rats. Am J Physiol Gastrointest Liver Physiol. 2008;295:G78-G87.

6. Coutts AA, Izzo AA. The gastrointestinal pharmacology of cannabinoids: an update. Curr Opin Pharmacol. 2004;4:572-579.

7. Wright K, Rooney N, Feeney M, et al. Differential expression of cannabinoid receptors in the human colon: cannabinoids promote epithelial wound healing. Gastroenterology. 2005;129:437-453.

8. Pertwee RG. Cannabinoids and the gastrointestinal tract. Gut. 2001;48:859-867.

9. Boesmans W, Ameloot K, van den Abbeel V, et al. Cannabinoid receptor 1 signalling dampens activity and mitochondrial transport in networks of enteric neurones. Neurogastroenterol Motil. 2009;21:958-e77.

10. Hornby PJ, Prouty SM. Involvement of cannabinoid receptors in gut motility and visceral perception. Br J Pharmacol. 2004;141:1335-1345.

11. Pinto L, Capasso R, Di Carlo G, et al. Endocannabinoids and the gut. Prostaglandins Leukot Essent Fatty Acids. 2002;66:333-341.

12. Yuece B, Sibaev A, Broedl UC, et al. Cannabinoid type 1 receptor modulates intestinal propulsion by an attenuation of intestinal motor responses within the myenteric part of the peristaltic reflex. Neurogastroenterol Motil. 2007;19:744-753.

13. Izzo AA, Mascolo N, Pinto $L$, et al. The role of cannabinoid receptors in intestinal motility, defaecation and diarrhoea in rats. Eur J Pharmacol. 1999;384:37-42.

14. Storr MA, Yuce $B$, Andrews $C N$, et al. The role of the endocannabinoid system in the pathophysiology and treatment of irritable bowel syndrome. Neurogastroenterol Motil. 2008;20:857-868.

15. Adami M, Zamfirova R, Sotirov E, et al. Gastric antisecretory effects of synthetic cannabinoids after central or peripheral administration in the rat. Brain Res Bull. 2004;64:357-361.

16. DiPatrizio NV, Astarita G, Schwartz G, et al. Endocannabinoid signal in the gut controls dietary fat intake. Proc Natl Acad Sci U S A. 2011;108:12904-12908.

17. DiPatrizio NV, Igarashi $M$, Narayanaswami V, et al. Fasting stimulates 2-AG biosynthesis in the small intestine: role of cholinergic pathways. Am J Physiol Regul Integr Comp Physiol. 2015;309:R805-R813.

18. Argueta DA, DiPatrizio NV. Peripheral endocannabinoid signaling controls hyperphagia in western diet-induced obesity. Physiol Behav. 2017;171:32-39.

19. Van Sickle MD, Duncan M, Kingsley PJ, et al. Identification and functional characterization of brainstem cannabinoid CB2 receptors. Science. 2005;310:329-332.

20. Onaivi ES. Neuropsychobiological evidence for the functional presence and expression of cannabinoid CB2 receptors in the brain. Neuropsychobiology. 2006;54:231-246.

21. Storr M, Gaffal E, Saur D, et al. Effect of cannabinoids on neural transmission in rat gastric fundus. Can J Physiol Pharmacol. 2002;80:67-76.
22. Berdyshev EV. Cannabinoid receptors and the regulation of immune response. Chem Phys Lipids. 2000;108:169-190.

23. Izzo AA. The cannabinoid $\mathrm{CB}(2)$ receptor: a good friend in the gut. Neurogastroenterol Motil. 2007;19:704-708.

24. Izzo AA, Fezza F, Capasso R, et al. Cannabinoid CB1-receptor mediated regulation of gastrointestinal motility in mice in a model of intestinal inflammation. Br J Pharmacol. 2001;134:563-570.

25. Calabrese $C$, Spisni E, Liguori G, et al. Potential role of the cannabinoid receptor $C B$ in the pathogenesis of erosive and non-erosive gastrooesophageal reflux disease. Aliment Pharmacol Ther. 2010;32:603-611.

26. Yang H, Zhou J, Lehmann C. GPR55-a putative "type 3" cannabinoid receptor in inflammation. J Basic Clin Physiol Pharmacol. 2016;27:297-302.

27. Li K, Fichna J, Schicho R, et al. A role for O-1602 and G protein-coupled receptor GPR55 in the control of colonic motility in mice. Neuropharmacology. 2013;71:255-263.

28. D'Argenio G, Petrosino S, Gianfrani C, et al. Overactivity of the intestinal endocannabinoid system in celiac disease and in methotrexate-treated rats. J Mol Med (Berl). 2007;85:523-530.

29. Guagnini F, Valenti M, Mukenge $S$, et al. Neural contractions in colonic strips from patients with diverticular disease: role of endocannabinoids and substance P. Gut. 2006;55:946-953.

30. Ligresti A, Bisogno T, Matias I, et al. Possible endocannabinoid control of colorectal cancer growth. Gastroenterology. 2003;125:677-687.

31. Pertwee RG. Emerging strategies for exploiting cannabinoid receptor agonists as medicines. Br J Pharmacol. 2009;156:397-411.

32. Dickman R, Shapiro M, Malagon IB, et al. Assessment of 24-h oesophageal $\mathrm{pH}$ monitoring should be divided to awake and asleep rather than upright and supine time periods. Neurogastroenterol Motil. 2007;19:709-715.

33. Lehmann A, Blackshaw LA, Branden L, et al. Cannabinoid receptor agonism inhibits transient lower esophageal sphincter relaxations and reflux in dogs. Gastroenterology. 2002;123:1129-1134.

34. Mostafeezur RM, Zakir HM, Takatsuji H, et al. Cannabinoids facilitate the swallowing reflex elicited by the superior laryngeal nerve stimulation in rats. PLoS One. 2012;7:e50703.

35. Beaumont $H$, Jensen J, Carlsson A, et al. Effect of delta9tetrahydrocannabinol, a cannabinoid receptor agonist, on the triggering of transient lower oesophageal sphincter relaxations in dogs and humans. Br J Pharmacol. 2009;156:153-162.

36. Scarpellini E, Blondeau K, Boecxstaens V, et al. Effect of rimonabant on oesophageal motor function in man. Aliment Pharmacol Ther. 2011;33:730-737.

37. Luquiens A, Lourenco N, Benyamina A, et al. Self-medication of achalasia with cannabis, complicated by a cannabis use disorder. World J Gastroenterol. 2015;21:6381-6383.

38. Gyawali CP. Achalasia: new perspectives on an old disease. Neurogastroenterol Motil. 2016;28:4-11.

39. Malik Z, Baik D, Schey R. The role of cannabinoids in regulation of nausea and vomiting, and visceral pain. Curr Gastroenterol Rep. 2015;17:429.

40. Dent J, Dodds WJ, Friedman RH, et al. Mechanism of gastroesophageal reflux in recumbent asymptomatic human subjects. J Clin Invest. 1980;65:256-267.

41. Mittal RK, Holloway RH, Penagini R, et al. Transient lower esophageal sphincter relaxation. Gastroenterology. 1995;109:601-610.

42. Partosoedarso ER, Abrahams TP, Scullion RT, et al. Cannabinoid1 receptor in the dorsal vagal complex modulates lower oesophageal sphincter relaxation in ferrets. J Physiol. 2003;550(Pt 1):149-158.

43. Van Sickle MD, Oland LD, Ho W, et al. Cannabinoids inhibit emesis through $\mathrm{CB} 1$ receptors in the brainstem of the ferret. Gastroenterology. 2001;121:767-774.

44. Bifulco M, Grimaldi C, Gazzerro P, et al. Rimonabant: just an antiobesity drug? current evidence on its pleiotropic effects. Mol Pharmacol. 2007;71:1445-1456.

45. Pauwels A, Altan E, Tack J. The gastric accommodation response to meal intake determines the occurrence of transient lower esophageal sphincter relaxations and reflux events in patients with gastroesophageal reflux disease. Neurogastroenterol Motil. 2014;26:581-588.

46. Ameloot $K$, Janssen $P$, Scarpellini $E$, et al. Endocannabinoid control of gastric sensorimotor function in man. Aliment Pharmacol Ther. 2010;31:1123-1131.

47. Lee KJ, Vos R, Janssens J, et al. Differential effects of baclofen on lower oesophageal sphincter pressure and proximal gastric motility in humans. Aliment Pharmacol Ther. 2003;18:199-207. 
48. McCallum RW, Soykan I, Sridhar KR, et al. Delta-9-tetrahydrocannabinol delays the gastric emptying of solid food in humans: a double-blind, randomized study. Aliment Pharmacol Ther. 1999;13:77-80.

49. Bateman DN. Delta-9-tetrahydrocannabinol and gastric emptying. $\mathrm{Br}$ J Clin Pharmacol. 1983;15:749-751.

50. Esfandyari T, Camilleri M, Ferber I, et al. Effect of a cannabinoid agonist on gastrointestinal transit and postprandial satiation in healthy human subjects: a randomized, placebo-controlled study. Neurogastroenterol Motil. 2006;18:831-838.

51. Finizia $C$, Lundell $L$, Cange $L$, et al. The effect of cisapride on oesophageal motility and lower sphincter function in patients with gastrooesophageal reflux disease. Eur J Gastroenterol Hepatol. 2002;14:9-14.

52. Ameri A. The effects of cannabinoids on the brain. Prog Neurobiol. 1999;58:315-348.

53. Plowright AT, Nilsson $K$, Antonsson $M$, et al. Discovery of agonists of cannabinoid receptor 1 with restricted central nervous system penetration aimed for treatment of gastroesophageal reflux disease. J Med Chem. 2013;56:220-240.

54. Blondeau K, Boecxstaens V, Rommel N, et al. Baclofen improves symptoms and reduces postprandial flow events in patients with rumination and supragastric belching. Clin Gastroenterol Hepatol. 2012;10:379-384.

55. Plan EL, Ma G, Nagard M, et al. Transient lower esophageal sphincter relaxation pharmacokinetic-pharmacodynamic modeling: count model and repeated time-to-event model. J Pharmacol Exp Ther. 2011;339: 878-885.

56. Palombini BC, Villanova $C A$, Araujo $E$, et al. A pathogenic triad in chronic cough: asthma, postnasal drip syndrome, and gastroesophageal reflux disease. Chest. 1999;116:279-284.

57. Cui YY, D'Agostino B, Risse PA, et al. Cannabinoid $C B(2)$ receptor activation prevents bronchoconstriction and airway oedema in a model of gastro-oesophageal reflux. Eur J Pharmacol. 2007;573: 206-213.

58. Barnes PJ. The problem of cough and development of novel antitussives. Pulm Pharmacol Ther. 2007;20:416-422.

59. Galmiche JP, Clouse RE, Balint A, et al. Functional esophageal disorders. Gastroenterology. 2006;130:1459-1465.

60. Aziz Q, Fass R, Gyawali CP, et al. Functional esophageal disorders. Gastroenterology. 2016;130:1459-1465.

61. Beltramo M. Cannabinoid type 2 receptor as a target for chronic-pain. Mini Rev Med Chem. 2009;9:11-25.

62. Wright KL, Duncan M, Sharkey KA. Cannabinoid CB2 receptors in the gastrointestinal tract: a regulatory system in states of inflammation. $\mathrm{Br}$ J Pharmacol. 2008;153:263-270.

63. Kikuchi A, Ohashi K, Sugie $Y$, et al. Pharmacological evaluation of a novel cannabinoid 2 (CB2) ligand, PF-03550096, in vitro and in vivo by using a rat model of visceral hypersensitivity. J Pharmacol Sci. 2008;106: 219-224.

64. Bingham B, Jones PG, Uveges AJ, et al. Species-specific in vitro pharmacological effects of the cannabinoid receptor 2 (CB2) selective ligand AM1241 and its resolved enantiomers. Br J Pharmacol. 2007;151:1061-1070.

65. Clapper JR, Moreno-Sanz G, Russo R, et al. Anandamide suppresses pain initiation through a peripheral endocannabinoid mechanism. Nat Neurosci. 2010;13:1265-1270.

66. Malik Z, Bayman L, Valestin J, et al. Dronabinol increases pain threshold in patients with functional chest pain: a pilot double-blind placebocontrolled trial. Dis Esophagus. 2017;30:1-8.

67. Sarfaraz S, Adhami VM, Syed DN, et al. Cannabinoids for cancer treatment: progress and promise. Cancer Res. 2008;68:339-342.

68. Bedoya F, Meneu JC, Macias MI, et al. Mutation in CNR1 gene and VEGF expression in esophageal cancer. Tumori. 2009;95:68-75.

69. Hijiya N, Shibata T, Daa T, et al. Overexpression of cannabinoid receptor 1 in esophageal squamous cell carcinoma is correlated with metastasis to lymph nodes and distant organs, and poor prognosis. Pathol Int. 2017;67:83-90.

70. Azofeifa A, Mattson ME, Schauer G, et al. National estimates of marijuana use and related indicators - national survey on drug use and health, united states, 2002-2014. MMWR Surveill Summ. 2016;65:1-28.

71. Rock EM, Parker LA. Cannabinoids as potential treatment for chemotherapyinduced nausea and vomiting. Front Pharmacol. 2016;7:221.

Cite this article as: Gotfried J, Kataria R, Schey R (2017) Review: the role of cannabinoids on esophageal function: what we know thus far, Cannabis and Cannabinoid Research 2:1, 252-258, DOI: 10.1089/ can.2017.0031.

$\begin{aligned} & \text { Abbreviations Used } \\ & \mathrm{CBRs}=\text { cannabinoid receptors } \\ & \mathrm{CNS}=\text { central nervous system } \\ & \mathrm{ECS}=\text { endocannabinoid system } \\ & \mathrm{ENS}=\text { enteric nervous system } \\ & \mathrm{ERD}=\text { erosive esophageal reflux disease } \\ & \mathrm{GERD}=\text { gastroesophageal reflux disease } \\ & \mathrm{GI}=\text { gastrointestinal } \\ & \mathrm{GPR} 55=\text { G-protein receptor } 55 \\ & \mathrm{NERD}=\text { nonerosive esophageal reflux disease } \\ & \mathrm{THC}=\text { tetrahydrocannabinol } \\ & \mathrm{TLESRs}=\text { transient lower esophageal sphincter relaxations } \\ & \mathrm{WD}=\text { Western diet }\end{aligned}$

\section{Publish in Cannabis and Cannabinoid Research}

Cannabis and

Cannabinoid

Research

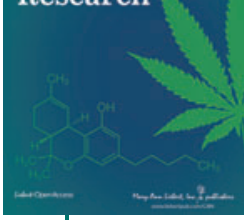

- Immediate, unrestricted online access

- Rigorous peer review

- Compliance with open access mandates

- Authors retain copyright

- Highly indexed

- Targeted email marketing

liebertpub.com/can 